\title{
1. Forging ahead with innovation: the importance of institutions and factor markets to the continued development of the BRICS
}

\author{
Ben L. Kedia, Rama Krishna Reddy, and \\ Tsvetomira V. Bilgili
}

\section{INTRODUCTION}

Over the next 50 years, Brazil, Russia, India and China - the BRIC economies could become a much larger force in the world economy. We map out GDP growth, income per capita and currency movements in the BRIC economies until 2050. The results are startling. If things go right, in less than 40 years, the BRIC economies together could be larger than the G6 in US dollar terms. By 2025 they could account for over half the size of the G6. Of the current G6, only the US and Japan may be among the six largest economies in US dollar terms in 2050. (Wilson and Purushothaman, 2003: 1)

No idea has done more to muddle thinking about the global economy than that of the BRIC. Other than being the largest economies in their respective regions, the big four emerging markets never had much in common. They generate growth in different and often competing ways - Brazil and Russia, for example, are major energy producers that benefit from high energy prices, whereas India, as a major energy consumer, suffers from them. Except in highly unusual circumstances, such as those of the last decade, they are unlikely to grow in unison. (Sharma, 2012a: 4)

In a Goldman Sachs global economics report a decade ago, "Dreaming with BRICs: The Path to 2050," Wilson and Purushothaman (2003) put forth the idea that the BRIC emerging economies (Brazil, Russia, India, and China), which had been growing at high rates, will continue their rapid progress and soon will surpass the G7 nations. Specifically, the authors submit that the combined GDP of the BRICs will surpass that of the G7 nations by the year 2035. In 2010, the lower case in the BRICs acronym transformed into a capital "S," when South Africa was added to the group (Tostevin, 2010). South Africa is already a member of the G20 nations and 
the largest African economy. With its addition to the BRICs, the group now includes emerging markets from three continents (The Economist, 2013a).

The projections of the growth of the BRICS were based on the condition of a set of core factors that are likely to promote long-term growth, namely, macroeconomic stability, institutional capacity, openness, and education (Wilson and Purushothaman, 2003). While certainly progress has been made by the BRICS economies on some of these dimensions, there are concerns of their ability to keep these developments on track (The Economist, 2013b). More importantly, the BRICS have been accused of not being able to innovate (Beausang, 2012), a factor believed to be crucial to sustained economic growth (Cohen, 2011). Furthermore, there are indications that the BRICS countries have differential priorities and strategies for growth and thus "generate growth in different and often competing ways" (Sharma, 2012a: 4).

Recent research has confirmed that emerging economies are heterogeneous in terms of the development of their institutions and factor markets (Hoskisson, Wright, Filatotchev, and Peng, 2013). While factors are the "more tangible production factors, such as physical infrastructure, available to firms", institutions refer to the "less tangible forms of support, such as judiciary efficiency that facilitate transactions" (Wan and Hoskisson, 2003: 28). As such, factors such as physical infrastructure, financial resources, labor quality and educational attainment are key in enabling countries to create wealth. On the other hand, political, legal, and societal institutions govern the behavior of economic actors and the market's competitive dynamics by influencing the costs of transactions (North, 1990; Peng and Heath, 1996). As such, heterogeneity in terms of the levels of development of BRICS countries' institutions and factor markets is likely to have implications for their innovation capacity and ultimately, economic growth.

In this chapter, we attempt to answer the following research questions: Are BRICS living up to the expectations? And, what are the contributing factors to ensuring their sustained growth in the future? We build on insights from economics to suggest that differences in the level of institutional and factor market development of the BRICS contribute to their non-uniform growth through their influence on innovation. Despite the appeal of contributing a country's innovation capacity to the level of its institutional and factor market development, research examining these relationships in the context of the BRICS economies is rare. As such, this study offers valuable contributions to research on emerging markets and the role of innovation in their development.

The chapter is structured as follows: In the following section we 
introduce the BRICS concept and discuss the state of their development in terms of institutions and factor markets. Then, we propose a relationship between innovation and sustained economic growth. Next, we develop hypotheses regarding the role of institutional and factor market development and innovation. We then describe our data, variables and methods, followed by the results of the analysis. Last, we discuss our findings, limitations and future research.

\section{THEORETICAL BACKGROUND}

\section{Dreaming with BRICS}

Over a decade ago, Jim O'Neill of Goldman Sachs, coined the term BRICs to refer to the, at the time, world's fastest growing emerging economies of Brazil, Russia, India, and China in terms of GDP and population productivity. Since then, South Africa was added to the group, which is now referred to as the BRICS. The acronym has become a conventional term that groups these economies despite the fact that they remain set in their ways and follow different paths of development (Yardley, 2012). Furthermore, "a problem with thinking in acronyms is that once one catches on, it tends to lock analysts into a worldview that may soon be outdated" (Sharma, 2012a: 4). Sharma also notes that the significant growth BRICS experienced in the last decade may be largely due to the fact that their starting point was quite low, allowing for dramatic changes to unfold; however, this "happy situation" is unlikely to endure. This argument is in line with the "catch-up hypothesis", which suggests that countries' "productivity growth rates tend to vary inversely with productivity levels" (Abramovitz, 1986: 385). Specifically, this premise suggests that when comparing among countries, the ones that are at low levels of development tend to initially experience higher growth rates. However, as they catch-up and the gap in productivity levels decreases, their potential to achieve high growth rates weakens (Abramovitz, 1986).

\section{Dreams Shattered?}

Recent data suggest that, aside from China, the BRICS economies are not living up to the expectations set forth by Wilson and Purushothaman (2003), questioning the meaningfulness of including Brazil, Russia, India, and South Africa in the same group (Badkar, 2013).

Figure 1.1 displays the GDP annual growth rates of each of the BRICS economies and the USA as a benchmark. For instance, Russia experienced 


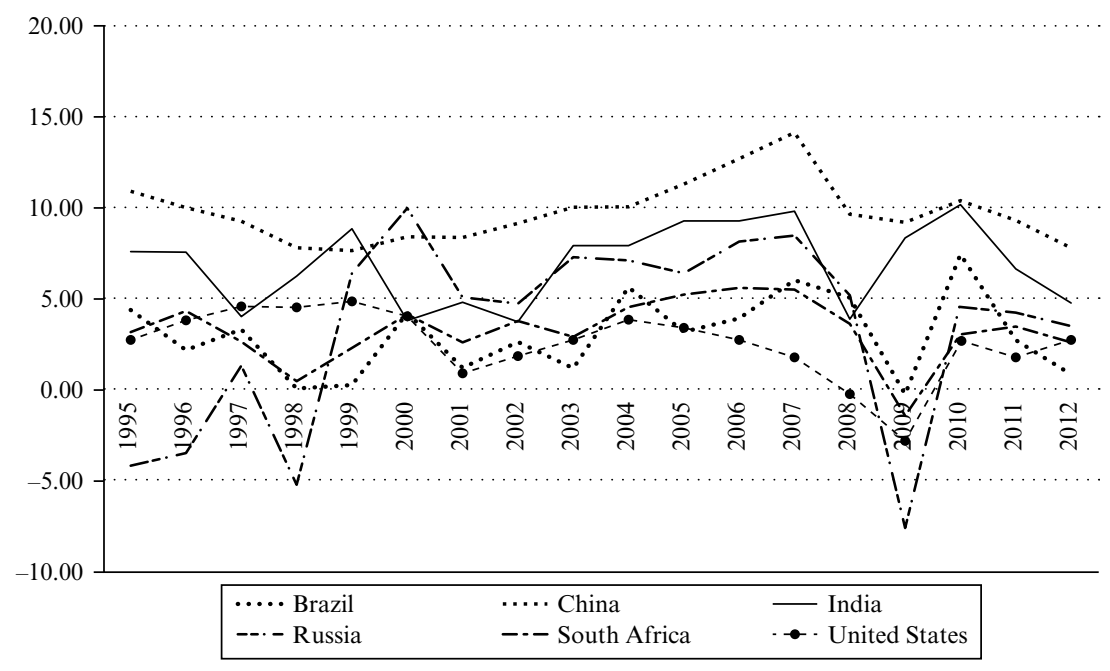

Source: World Bank.

Figure 1.1 GDP growth

powerful growth during the 2000 decade largely as a result of reliance on the oil and gas sectors financed by a class of billionaires (Beausang, 2012; Sharma, 2012b). Thus, as a result of the global recession, commodity prices fell dramatically, hurting Russia's growth. Indeed, Sharma points out that "Russia remains a member of the BRICS, if only because the term sounds better with an R" (2012a: 5). In a similar vein, South Africa and Brazil's growth depended largely on commodity prices (BRICS, 2013; Sharma, 2012b). The decreasing demand for these commodities may explain the sluggish growth these BRICS economies have experienced in the last five years.

\section{The Influence of Institutions and Factor Markets}

It has long been acknowledged that a country's prospect for economic growth is influenced by its production factor endowments and the efficiency with which they are used (Porter, 2000). Such endowments include advanced factors such as infrastructure, capital and financial resources, and human factors, which refer to the availability of quality labor in a country (Wan and Hoskisson, 2003). However, the institutional economics perspective recognizes the role of institutions in addition to production factors in influencing economic exchange (North, 1990). North's view of 
institutions as "the rule of the game" suggests that while strong institutions may facilitate transactions and reduce costs of inter-firm transactions, weak institutions will ultimately render utilization of factors inefficient.

Based on the assumption that country environments consist of factors and institutions, in a recent study, Hoskisson et al. (2013) proposed a typology of emerging markets, which categorizes countries based on these two dimensions. Using data from the Global Competitiveness Report (GCR) 2011-2012, Hoskisson et al. (2013) conducted cluster analysis to determine the way 60 emerging economies group based on their level of factor market and institutional development. The results confirmed there is high variability among emerging economies in terms of where they fall on these dimensions. Hoskisson et al. (2013) measured a country's factor markets with three indicators, namely, infrastructure, macroeconomic environment, and health and primary education pillars of the Global Competitiveness Index (GCI). Institutional development is measured with the overall score on the institutions pillar, which encompasses evaluations of the country's public as well as private institutions. Similarly, we obtained data on levels of factor market and institutional development of the BRICS and the G7 nations from the GCR 2006-2007 and GCR 2013-2014 to illustrate how these economies evolved in a 7-year period; data are presented in Table 1.1. As depicted in Figure 1.2, important differences can be detected in terms of where the BRICS countries stand compared to each other and how they have changed from 2006 to 2013.

Table 1.1 GCI factor market and institutional development scores

\begin{tabular}{|c|c|c|c|c|c|}
\hline Country & Infrastructure & $\begin{array}{c}\text { Macroeconomic } \\
\text { environment }\end{array}$ & $\begin{array}{l}\text { Health and } \\
\text { primary } \\
\text { education }\end{array}$ & $\begin{array}{c}\text { Public } \\
\text { institutions }\end{array}$ & $\begin{array}{c}\text { Private } \\
\text { institutions }\end{array}$ \\
\hline \multicolumn{6}{|c|}{ GCI 2006-2007 } \\
\hline Brazil & 3.15 & 3.70 & 6.04 & 3.05 & 4.34 \\
\hline China & 3.73 & 6.45 & 5.68 & 3.55 & 3.64 \\
\hline India & 3.39 & 4.57 & 5.47 & 4.31 & 4.95 \\
\hline Russia & 3.27 & 5.43 & 5.79 & 2.72 & 3.61 \\
\hline South Africa & 4.45 & 5.19 & 4.86 & 4.26 & 5.39 \\
\hline \multicolumn{6}{|c|}{ GCI 2013-2014 } \\
\hline Brazil & 4.02 & 4.63 & 5.43 & 3.55 & 4.28 \\
\hline China & 4.51 & 6.29 & 6.06 & 4.25 & 4.20 \\
\hline India & 3.65 & 4.10 & 5.30 & 3.75 & 4.19 \\
\hline Russia & 4.61 & 5.93 & 5.71 & 3.12 & 3.75 \\
\hline South Africa & 4.13 & 4.37 & 3.89 & 4.23 & 5.46 \\
\hline
\end{tabular}

Source: Global Competitiveness Report. 


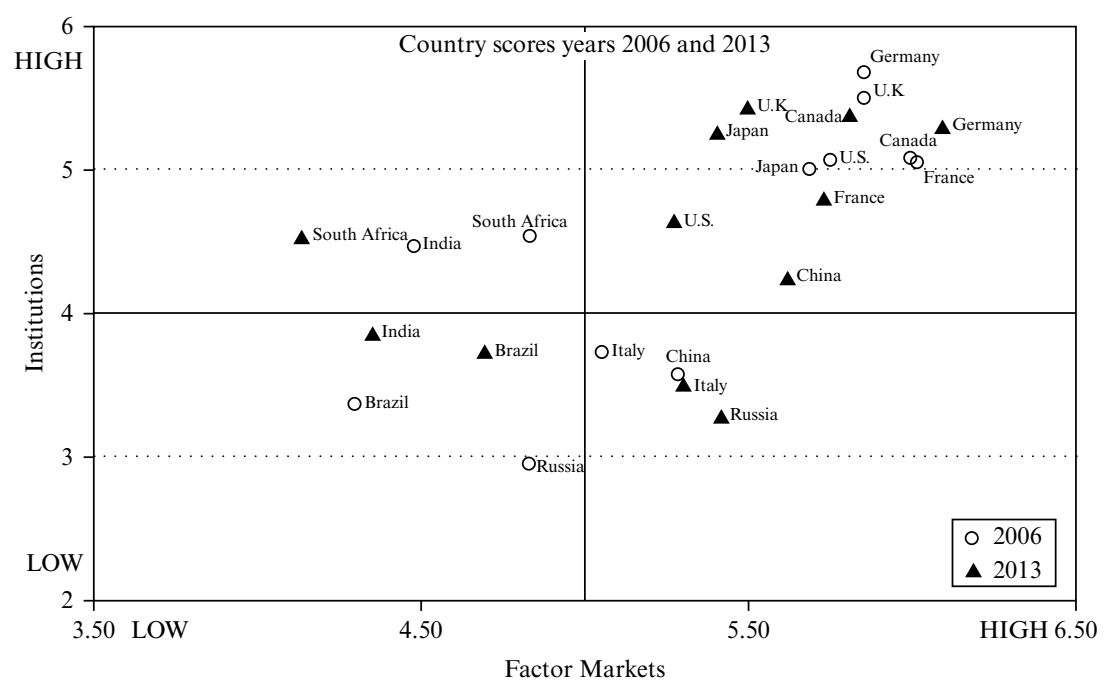

Source: Global Competitiveness Report.

Figure 1.2 Scatterplot of G7 and BRICS economies, years 2006 and 2013

\section{Year 2006}

In 2006, the country with the lowest factor market development was Brazil. While Brazil scored highest on health and education among the BRICS, its scores on infrastructure and macroeconomic environment were the lowest. India followed Brazil with slightly better factor market development. According to the GCI, India's level of health and education was relatively better developed than its macroeconomic environment and infrastructure. Russia and South Africa were at moderate levels of factor market development, however, the macroeconomic environment in these countries received a higher score than their infrastructure. From the BRICS economies, China was the nation with highest level of factor market development in 2006. While its infrastructure was ranked second among the BRICS and its health and education third, its macroeconomic environment received the highest score of the five.

In terms of institutional development, India and South Africa were rated significantly higher than all other BRICS nations. They received the highest scores of the five countries on both public and private institutions. Russia, on the other hand, had the lowest level of institutional development in terms of both public and private institutions, followed by Brazil and China. 


\section{Change 2006-2013}

Figure 1.2 also illustrates changes from 2006 to 2013 of each of the BRICS economies in terms of their factor market and institutional development. For instance, Brazil and Russia experienced a significant improvement in factor market development and a slight increase in the level of institutional development. Infrastructure and macroeconomic environment improved in both countries. Russia scored the same on health and education as in 2006, while Brazil received a lower score. In addition, both public and private institutions in Russia improved; however, public institutions recorded greater progress. Similarly, Brazil's public institutions improved between 2006 and 2013, while private institutions deteriorated. However, the level of factor market development of India and South Africa declined significantly in 2013. They received lower scores on both macroeconomic environment and health and education. South Africa's infrastructure received a lower score in 2013; however, India recorded a slight improvement. In terms of institutions, South Africa remained at a similar level, while India's public institutions deteriorated drastically. This deterioration in institutions in India is not surprising given the increase in corruption and decline in political stability over the seven-year period. In 2006, India was ranked 70th on the Corruption Perception Index, while in 2013 it dropped to 94 out of 177 countries. In terms of political stability, as measured by the World Bank Governance Indicators, India received a score of -1.06 in 2006 and a score of -1.25 in 2012 (scores range from approximately -2.5 [weak] to 2.5 [strong]), indicating decline in stability and weak governance. Last, between 2006 and 2013, China significantly improved in terms of both institutions and factor market development. From the three factor market development indicators, China improved significantly on both infrastructure and health and education between 2006 and 2013. Furthermore, both public and private institutions in China recorded notable progress.

Aside from Italy, the G7 nations occupy positions in the upper right quadrant of Figure 1.2, indicating their relatively better institutional and factor market development in comparison to the BRICS. However, with the exception of Germany and Italy, the G7 nations experienced decline in factor markets during the 2006-2013 period.

\section{The Role of Innovation for Sustained Economic Growth}

Innovation is perceived as a key driver of progress and economic growth (Lucas, 1988). There are two predominant perspectives on the determinants of growth: One views "resource accumulation" (King and Rebelo, 1990), while the other sees "industrial innovation" (Romer, 1990; Aghion 
and Howitt, 1990) as the main source of economic growth. The growth of emerging markets has been primarily resource-driven and as a result, these economies are experiencing diminishing growth rates (Krugman, 1994). To address this, our model suggests that sustained economic growth of the BRICS economies is dependent on the availability of factors; however, unless they result in the creation of innovation with the support of well-established institutions, these resources are unlikely to lead to sustained growth. We concur with the early growth theorists, like Schumpeter (1934) who argued that technological progress and advancement are essential for growth because 'innovation' leads to disruption of the market, replaces existing market leaders, and renders the accumulated resources unable to promote growth. As a result, in the long run, the sole accumulation of resources will lead to diminishing returns and consequently, such growth is unsustainable. Based on these arguments we suggest that sustainable economic growth can be achieved only if the BRICS are able to advance their innovation capacities. Therefore, we propose the following:

Proposition: Sustained economic growth of the BRICS countries will be dependent on the degree of innovation they are able to achieve.

While innovation is key to driving economic growth, we argue that the level of innovation in turn depends on the country's level of factor markets and institutional development. Our conceptual model is depicted in Figure 1.3. In the next section we develop hypotheses that link a country's institutions and factor market development to its innovation capacity.

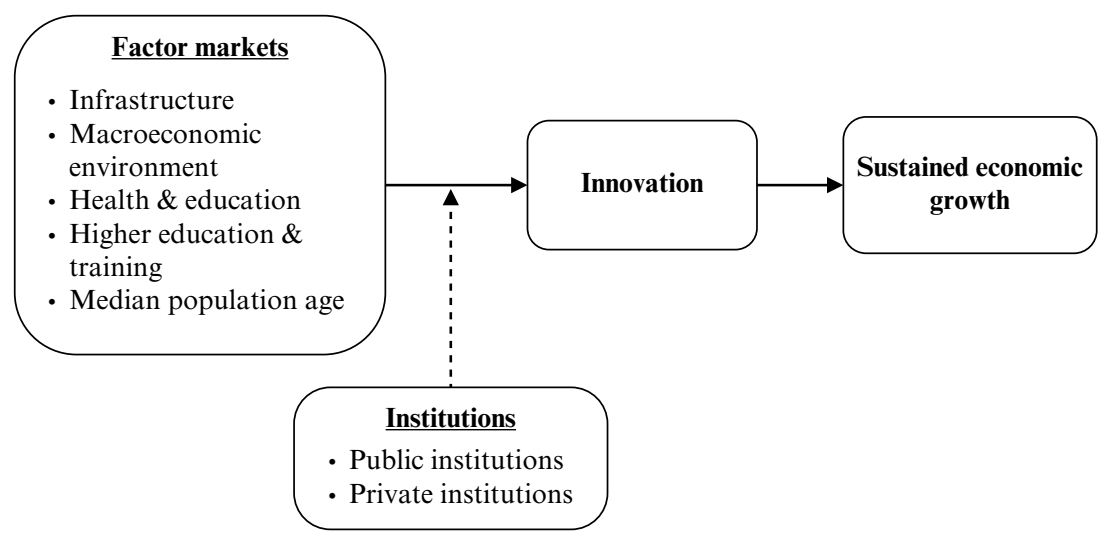

Figure 1.3 Conceptual model 


\section{HYPOTHESES DEVELOPMENT}

\section{The Influence of Factor Markets and Institutional Development}

Furman, Porter, and Stern define national innovation capacity, as "the ability of a country - as both a political and economic entity - to produce and commercialize a flow of new-to-the world technologies over the long term" (2002: 900). Success in innovation is determined by a variety of contextual and environmental factors (Roberts and Amit, 2003), which provide the resources that enable a country's transformative capabilities (Mankiw, Romer, and Weil, 1992; Wan, 2005).

For instance, access to factors such as human and financial capital (Wan, 2005) influences the capabilities of firms within a nation to contribute to the country's innovation. Human capital has long been viewed as key to a country's economic growth because of its relation to the rate of introduction of new products and services (Barro, 1991). Higher education attainment of the country's population results in higher quality labor force. As such, human factors contribute to a country's innovation capacity through the generation of innovative ideas and facilitation of the country's absorptive capacity (Wan and Hoskisson, 2003).

While the availability of highly educated and skilled human capital is a key prerequisite to generating innovative ideas (Porter and Stern, 2002), financial capital and infrastructure enable the acquisition and transformation of these resources into commercially valuable ends (Furman et al., 2002). Infrastructure development has also been linked to countries' level of productivity. Aschauer (1989) finds that lower productivity levels in the United States in the 1970s can be explained by a decrease in infrastructure investments. Infrastructure facilitates the "process of invention and the spread of new ideas" through rapid communication among innovators (Grossman and Helpman, 1993: xi). Furthermore, financial capital provides the resources firms need to engage in innovation activities (Levine, 1997).

Since environments as represented by their factor markets and institutions differ across countries, the opportunities and constraints that firms in these countries face are also likely to vary widely. While the BRICS economies have achieved some progress in the development of their factor markets (Hoskisson et al., 2013), some authors raise concerns over the strong focus of BRICS countries, especially China, on imitation rather than indigenous innovation (Beausang, 2012). This argument suggests that it is unlikely that the progress that the BRICS have achieved can provide them with a competitive advantage over developed countries. However, maintaining a fast pace of factor market 
development and ultimately innovation, have the potential to enable the BRICS countries to gain headway in this competitive race. Hence, we suggest the following:

Hypothesis 1: The degree of innovation achieved is a function of the country's factor market development.

Even if factors are abundant, they are unlikely to be efficiently utilized to produce innovation when the country's institutions are poorly developed (Hoskisson et al., 2013). As such, we argue for the joint influence of factor market and institutional development on countries' innovative capacity. While factors are necessary to ensure the availability of human capital necessary to generate ideas and the business sophistication and infrastructure to support such efforts, by setting the "rules of the game" (North, 1990) institutions exert influence on the cost of acquiring these resources (Wan, 2005) and on the way firms learn and acquire knowledge (Hitt, Li, and Worthington, 2005). Institutions refer to both public and private institutions within a society. On the one hand, legal and political institutions constitute the public dimension of institutions and represent the reliability and effectiveness of a country's governmental and judiciary system. Intellectual property rights protection, for instance, provides firms with the incentive to innovate as it ensures the generated knowledge cannot be exploited by competitors (Lim, 2009). Societal institutions, on the other hand, represent the private dimension of institutions that underline norms and values that guide individual and firm behavior in a society (Scott, 1995; Wan and Hoskisson, 2003). Knack and Keefer (1997) show that trust and civic norms inhibit opportunistic behavior, and as a result facilitate cooperation and the transfer of knowledge among economic actors.

Significant differences are evident in the level of development and stability of institutions within the BRICS nations (Hitt et al., 2005). Hitt et al. (2004) showed that differences in the stability of public and private institutions and the level of control exerted by governments had a profound influence on the actions taken by firms in these economies. In particular, the institutional arrangements in China provided greater certainty and lower risk to firms operating there. This provided favorable conditions for firms to establish a long-term orientation and to focus on strategic actions and innovative capacity development. The decentralized control and resulting uncertainty in Russia, on the other hand, further decreased their motivation and incentive to innovate (Hitt et al., 2005) as firms focused on their survival and pursued short-term strategies (Hitt et al, 2004). Hence, we suggest the following: 
Hypothesis 2: The relationship between a country's factor market development and its degree of innovation achieved is negatively moderated by the level of institutional development such that: the greater the level of institutional development of the country, the weaker the relationship between factor market development and degree of innovation achieved.

\section{METHODOLOGY}

\section{Data Collection and Sample}

Information on innovation, factor markets, and institutional development variables is obtained from the Global Competitiveness Report (GCR). The GCR is released by the World Economic Forum every year and its main objective is to assess and rank 148 world economies based on their level of competitiveness and capacity for economic growth. As such, the index implies that the more competitive an economy, the more likely it is to grow faster over time. The Global Competitiveness Index relies on twelve pillars each measured based on different aspects of competitiveness. The overall score for each pillar is measured on a scale from 1 to 7 with 7 indicating the highest level of competitiveness. The scores are computed using multiple indicators, which are mainly based on data from the World Economic Forum's Executive Opinion Survey and supplemented by data from other sources such as, the World Bank, International Monetary Fund, and World Trade Organization.

We use data for each of the BRICS economies and the G7 nations for the period 2006-2013.

\section{Variables}

\section{Dependent variable}

In our analysis, we use the overall score on the innovation pillar, which is based on seven separate indicators. Six of these indicators are items from the Executive Opinion Survey. An example item is 'In your country, how would you assess the quality of scientific research institutions?' $(1=$ extremely poor - among the worst in the world; $7=$ extremely good - among the best in the world). The seventh indicator is the number of applications filed under the Patent Cooperation Treaty (PCT) per million population and is obtained from the Organisation for Economic Co-operation and Development (OECD). 


\section{Independent variable}

In this study, we measure the country's factor markets with five indicators. We use country scores on the higher education and training pillar in addition to the infrastructure, macroeconomic environment, and health and primary education pillars from the GCI as used by Hoskisson et al. (2013). In addition, we include a fifth indicator representing the median age of the country's population. The scores on the four pillars are based on a mixture of Executive Opinion Survey items as well as hard data such as government budget balance, life expectancy at birth, and net primary education enrollment rate obtained from a variety of sources. Example of a survey item measuring country's infrastructure is 'How would you assess general infrastructure (e.g. transport, telephony, and energy) in your country?' ( 1 = extremely underdeveloped - among the worst in the world; 7 = extensive and efficient - among the best in the world). Data on median population age is obtained from the World Bank's World Development Indicators. Finally, to construct our factor markets variable we estimated latent variable scores using Smart Partial Least Squares (PLS) software in order to obtain yearly country scores for factor market development based on values on these five indicators.

\section{Moderator variable}

We operationalize institutional development by the score on the institutions pillar. This pillar is based on measures of private as well as public institutions from the Executive Opinion Survey. An example item is 'In your country, how strong is the protection of property rights, including financial assets?' ( 1 = extremely weak; 7 = extremely strong).

\section{Control variables}

We included a variable indicating the reliance of the country on natural resource exports measured by the natural resource exports as a percentage of GDP. Furthermore, we controlled for the size of the economy by including a variable indicating the total country population for each specific year. We $\log$ transformed both variables to normalize their distributions. Last, we controlled for the productive age population by accounting for the percentage of the population that is between the ages 16 and 62. We standardized the variable due to its highly skewed distribution. Data on all three control variables are obtained from the World Bank's World Development Indicators. We did not control for the effect of country group membership (BRICS vs. G7), since group membership (coded 1 when the country is a G7 nation and 0 when the country is a member of the BRICS) were highly positively correlated $(r>0.9)$ with our factor markets independent variable. 


\section{RESULTS}

We use hierarchical regression analysis to estimate the effects of factor markets development on innovation and the moderating role of institutions. Table 1.2 presents the means, standard deviations and pairwise correlations for the variables included in the analysis. The correlation coefficients between the independent variables show there are no reasons for concerns of multicollinearity in our analyses (all $\mathrm{r}<0.70$ ) (Pallant, 2010). Furthermore, an examination of the tolerance and VIF statistics shows VIF values are between 1.136 and 4.591, which is below the maximum acceptable value of 10 . The tolerance varies between 0.218 and 0.880 , which is also above the suggested cutoff point of 0.1 (Hair, Black, Babin, and Anderson, 2010).

\section{Hypotheses Testing}

The results of the regression analysis are displayed in Table 1.3. Model 1 includes the control variables natural resource exports, population and percentage of productive age population. In Model 2 the individual effects of factor markets development and institutions are introduced. Last, the interaction term is added in Model 3

The effects of natural resource exports are significant in Model 1 $(\beta=-0.635, p<0.01)$ and not significant in Models 2 and 3. The population control variable is significant in Models 2 and 3 ( $\beta=0.300, p<0.01$ and $\beta=0.267, p<0.01)$ and not significant in Model $1(\beta=-0.023$, $p>0.10)$. Finally, the coefficient of percentage of productive age population is significant only in Model $2(\beta=-0.184, p<0.01)$ and not significant in Models $1(\beta=-0.082, p>0.10)$ and $3(\beta=0.039, p>0.10)$.

Hypothesis 1 suggested that better factor market development associated with higher levels of innovation. Model 2 provides evidence of the positive relationship between factor markets and innovation in support of Hypothesis $1(\beta=0.584, p<0.01)$. Adjusted $R^{2}$ for this model is 0.848 , which shows significant improvement from Model 1.

Last, Hypothesis 2 posited that institutions negatively moderate the relationship between factor markets and innovation. This moderating effect of institutions is confirmed in Model 3 ( $\beta=-1.856, p<0.01)$, supporting Hypothesis 2 . Adjusted $R^{2}$ for the final model is 0.866 suggesting that Model 3 explains approximately 87 percent of the variance in our dependent variable.

In order to better interpret the interaction effect, we followed Aiken and West's (1991) approach and plotted innovation against three levels of factor markets for each of three levels of institutions (one standard 


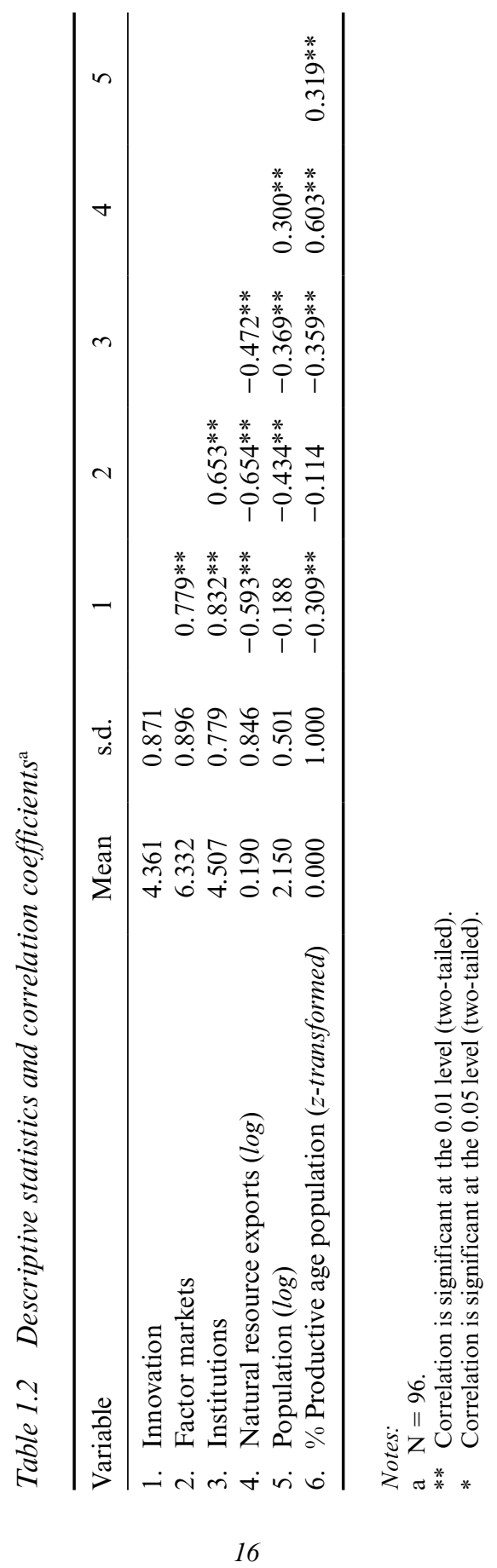


Table 1.3 Results of hierarchical regression analysis

\begin{tabular}{lccc}
\hline & Model 1 & Model 2 & Model 3 \\
\hline Control Variables & & & \\
Natural resource exports (log) & $-0.635^{* *}$ & 0.055 & -0.016 \\
Population (log) & -0.023 & $0.300^{* *}$ & $0.267^{* *}$ \\
\% Productive age population (z-transformed) & -0.082 & $-0.184^{* *}$ & 0.039 \\
Independent Variables & & & \\
Factor markets & & $0.584^{* *}$ & $1.274^{* *}$ \\
Institutions & & $0.522^{* *}$ & $1.849^{* *}$ \\
Interaction Term & & & $-1.856^{* *}$ \\
Factor markets*institutions & 0.335 & 0.848 & 0.866 \\
Adjusted $R^{2}$ & 96 & 96 & 96 \\
$N$ & & & \\
\hline
\end{tabular}

\section{Notes:}

Model 1 includes the control variables. Model 2 includes the independent variable and the moderator variable. Model 3 includes all prior variables plus the interaction term.

Figures represent standardized beta coefficients.

Dependent variable $=$ Innovation .

** Coefficient is significant at the 0.01 level.

* Coefficient is significant at the 0.05 level.

deviation below and one standard deviation above the mean). Figure 1.4 shows that while factor markets are positively associated with innovation, better developed institutions allow countries to achieve even higher levels of innovation. Moreover, the relationship between factor markets and innovation is stronger at low levels of institutional development. Accordingly, at high levels of institutional development, differences in factor markets have smaller effect on countries' innovation.

\section{DISCUSSION AND CONCLUSION}

\section{Economic Growth}

Innovation is viewed as a crucial factor that contributes to sustained economic growth (Cohen, 2011; Krugman, 1994; Schumpeter, 1934). Our paper contributes to this line of research by suggesting that the ability of the BRICS to maintain their high growth depends on their capacity to innovate. While the BRICS economies have experienced relatively high rates of growth in recent years, maintaining this progress requires greater emphasis on innovation (Beausang, 2012). Our data show that the mean 


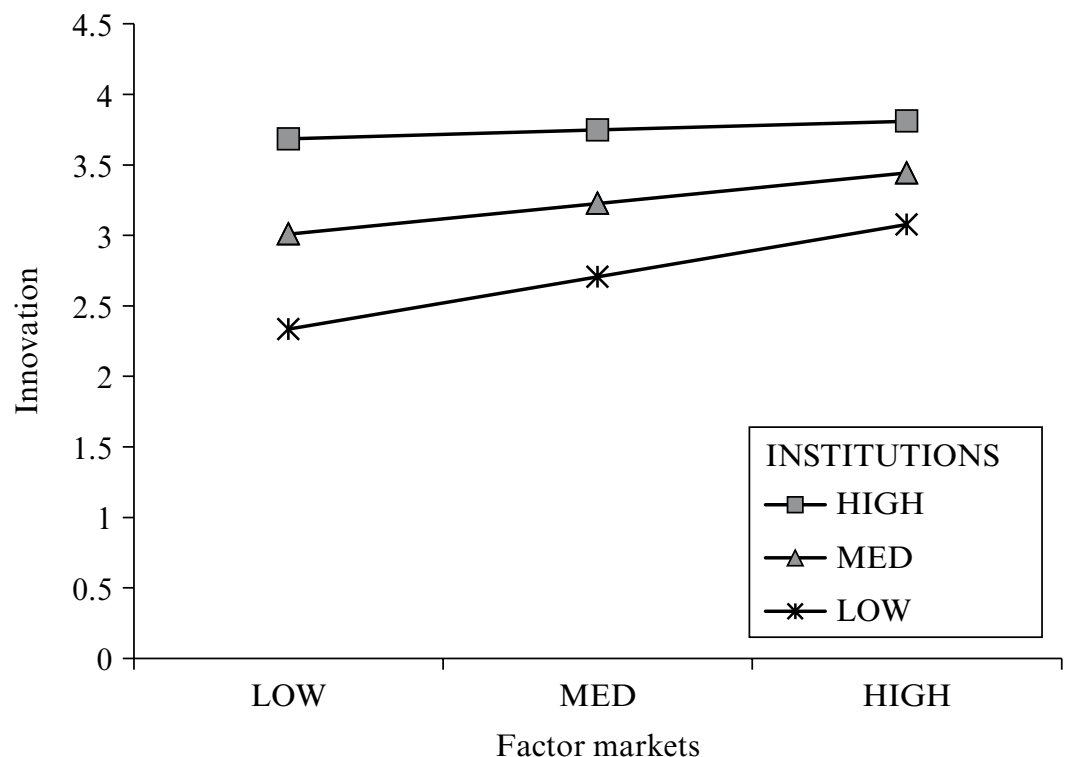

Figure 1.4 Moderating role of institutions

innovation of the BRICS countries is 3.582, which is much lower than that of the G7 countries (4.917). A t-test reveals that these differences in innovation are indeed significant $(t=-13.015, p<0.01)$. This shows that the BRICS have not yet caught up to the developed nations in terms of their capacity for innovation.

Our second contribution is to the literature on emerging markets and BRICS countries in particular. We provide empirical evidence of the strong relationship between factor market development and level of innovation. Thus, a country's capacity to innovate and ultimately achieve economic growth depends on the level of development of its factor markets. Therefore, differences among the BRICS countries in terms of their factor markets (Hoskisson et al., 2013) can explain why these countries have been growing at different rates.

Finally, we find that institutions weaken the relationship between factor markets development and innovation. This finding supports our argument that institutions are key in facilitating the efficient utilization of available factors in an economy. Specifically, while factors such as physical infrastructure, financial resources, labor quality, and educational attainment are key in enabling a country's transformative capabilities, institutions influence the costs of transactions (North, 1990; Peng and Heath, 1996). 


\section{Factor Markets and Innovation}

The results of our empirical analysis confirm that factors are significantly positively related to innovation. Thus, the more developed a country's factor market, the higher the level of innovation the country is able to achieve. The BRICS economies have made progress in the development of their factor markets between 2006 and 2013. Data also show significant increase in citable scientific publications by BRICS nations between 1996 and 2012. Specifically, Figure 1.5 shows that in 1996 these countries accounted for 9 percent of the total world publications, while their share in 2012 increased to 22 percent. Whereas, the BRICS economies still lag behind $\mathrm{G} 7$ nations, these data show they are moving in the right direction. Further development of BRICS' factor markets will provide support for increasing innovation; however, without sufficient improvement of their public and private institutions such increase is likely to be marginal.

\section{Moderating Role of Institutions}

While factors certainly play a key role in enabling innovation, the efficiency with which they can be exploited depends on the level of the country's institutional development (Hoskisson et al., 2013). Well-developed institutions can reduce the cost of acquiring the resources needed to innovate (Wan, 2005) and facilitate learning and acquisition of knowledge (Hitt et al., 2005).

The results of our analysis provide evidence that the level of a country's institutional development negatively moderates the relationship between factor markets and innovation. While better developed institutions allow countries to achieve even higher levels of innovation, differences can be seen in terms of the strength of the factor markets-innovation relationship at high versus low levels of institutional development. Specifically, as expected, the relationship between factor markets and innovation is stronger at low levels of institutional development. This finding shows that as institutions develop, having low versus high factor market development makes much less of a difference in terms of achieving innovation than when institutions are poorly developed. As a result, countries can achieve higher levels of innovation with low factor markets and high institutional development than with high factor markets but low institutional development. Institutions facilitate the efficient utilization of factors. Furthermore, stronger institutions, such as better protection of property rights, provide incentives to firms to innovate (Lim, 2009). Their absence, on the other hand may be associated with greater reliance on imitation rather than original innovation (Beausang, 2012). 
1996

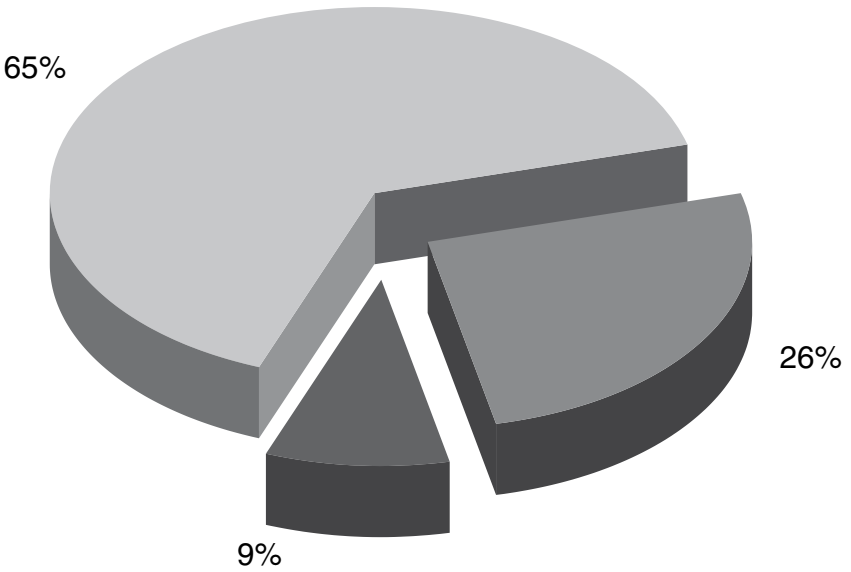

BRICS

G7

ROW

\section{2}

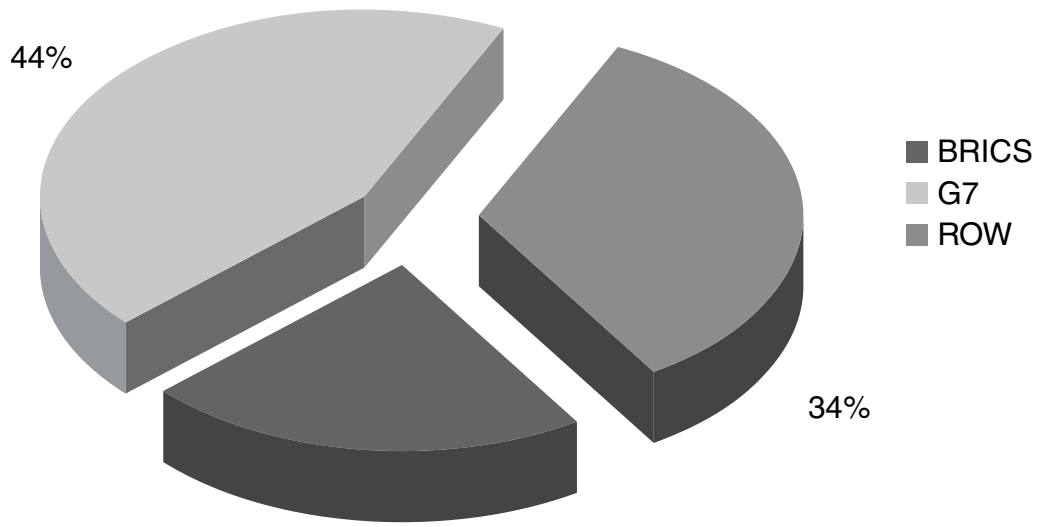

$22 \%$

Source: SCImago Journal and Country Rank, accessed from www.scimagojr.com.

Figure 1.5 Percentage of world citable scientific publications: BRICS, G7, and the rest of the world ( $R O W$ )

BRICS economies remain heterogeneous in terms of their factor markets and institutional development as well as their capacity for innovation. Overall, these countries have made significant progress in developing their factor markets and institutions; however, sustaining their economic growth will depend on their ability to support innovation. Therefore, whether they 
forge ahead or fall behind is determined by their commitment to foster innovation.

\section{REFERENCES}

Abramovitz, M. (1986) "Catching up, forging ahead, and falling behind," Journal of Economic History, 46 (2), 385-406.

Aghion, P. and P. Howitt (1990) "A model of growth through creative destruction," Working Paper Series, Cambridge, MA: National Bureau of Economic Research.

Aiken, L. S. and S. G. West (1991) Multiple Regression: Testing and Interpreting Interactions. London: Sage Publications.

Aschauer, D. A. (1989) "Is public expenditure productive?," Journal of Monetary Economics 23, 177-200.

Badkar, M. (2013) "Why three of the four BRICs are failing to meet the world's expectations," Business Insider, October. Available at: http://www.businessinsider. com/why-china-was-the-only-BRIC-to-succeed-2013-10.

Barro, R. (1991) "Economic growth in a cross-section of countries," Quarterly Journal of Economics 106, 407-444.

Beausang, F. (2012) Globalization and the BRICs: Why the BRICs Will Not Rule the World for Long, New York: Palgrave Macmillan.

BRICS (2013) "South Africa in BRICS." Available at: http://www.brics5.co.za/ about-brics/south-africa-in-brics.

Cohen, A. J. (2011) "Innovation and economic growth," Goldman Sachs Global Investment Research. Available at: http://www.goldmansachs.com/our-thinking/ archive/archive-pdfs/gsr.pdf

Furman, J. L., M. E. Porter, and S. Stern (2002) "The determinants of national innovating capacity," Research Policy 31, 899-933.

Grossman, G. M. and E. Helpman (1993) Innovation and Growth in the Global Economy, Cambridge, MA: MIT Press.

Hair Jr., J. F., W. C. Black, B. J. Babin, and R. E. Anderson (2010) Multivariate Analysis, 7th edn., Upper Saddle River, NJ: Prentice Hall.

Hitt, M. A., D. Ahlstrom, M. T. Dacin, E. Levitas, and L. Svobodina (2004) "The institutional effects on strategic alliance partner selection in transition economies: China versus Russia," Organization Science 15 (2), 173-185.

Hitt, M. A., H. Li, and W. J. Worthington IV (2005) "Emerging markets as learning laboratories: Learning behaviors of local firms and foreign entrants in different institutional contexts," Management and Organization Review 1 (3), 353-380.

Hoskisson, R. E., M. Wright, I. Filatotchev, and M. Peng (2013) "Emerging multinationals from mid-range economies: The influence of institutions and factor markets," Journal of Management Studies 50 (7), 1295-1321.

King, R. G. and S. Rebelo (1990) "Public policy and economic growth: Developing neoclassical implications," Working Paper Series, Cambridge, MA: National Bureau of Economic Research.

Knack, S. and P. Keefer (1997) "Does social capital have an economic payoff? A cross-country investigation," The Quarterly Journal of Economics 112 (4), 1251-1288.

Krugman, P. (1994) “The myth of Asia's miracle," Foreign Affairs 73 (6), 62-78. 
Levine, R. (1997) "Financial development and economic growth: Views and agendas," Journal of Economic Literature 35 (2), 688-726.

Lim, K. (2009) "The many faces of absorptive capacity: Spillovers of copper interconnect technology for semiconductor chips," Industrial and Corporate Change 18 (6), 1249-1284.

Lucas, R. E. Jr. (1988) "On the mechanics of development planning," Journal of Monetary Economics 22, 3-42.

Mankiw, N. G., D. Romer, and D. N. Weil (1992) "A contribution to the empirics of economic growth,” NBER Working Paper. (DOI): 10.3386/w3541.

North, D. C. (1990) Institutions, Institutional Change, and Economic Performance. Cambridge, MA: Harvard University Press.

Pallant, J. (2010) SPSS Survival Manual: A Step by Step Guide to Data Analysis using the SPSS Program 4th edn. Crows Nest, Australia: Allen \& Unwin.

Peng, M. and P. S. Heath (1996) "The growth of the firm in planned economies in transition: Institutions, organizations, and strategic choice," Academy of Management Review 21 (2), 496-528.

Porter, M. E. (2000) "Location, competition, and economic development: Local clusters in a global economy," Economic Development Quarterly 14 (1), 15-34.

Porter, M. E. and S. Stern (2002) "National innovative capacity," in M. E. Porter, J. D. Sachs, P. K. Cornelius, J. W. McArthur, and K. Schwab (eds.), The Global Competitiveness Report 2001-2002, pp.102-118, New York: Oxford University Press.

Roberts, P. W. and R. Amit (2003) "The dynamics of innovative activity and competitive advantage: The case of Australian retail banking, 1981 to 1995," Organization Science 14 (2), 107-122.

Romer, P. M. (1990) "Endogenous technological change," Journal of Political Economy, S71-S102.

Schumpeter, J. A. (1934) The Theory of Economic Development. An Inquiry into Profits, Capital, Credit, Interest, and the Business Cycle. New Brunswick, NJ, London: Transaction Publishers.

Scott, W. R. (1995) Institutions and Organizations. Thousand Oaks, CA: Sage.

Segerstrom, P. S. (1991) "Innovation, imitation, and economic growth," Journal of Political Economy 99 (4), 807-827.

Sharma, R. (2012a) "Broken BRICs: Why the rest stopped rising," Foreign Affairs $91(8), 2-7$.

Sharma, R. (2012b) "Bearish on Brazil: The commodity slowdown and the end of the magic moment," Foreign Affairs 91 (3), 80-87.

The Economist (2013a) "Why is South Africa included in the BRICS?," The Economist, March 29. Available at: http://www.economist.com/blogs/ economist-explains/2013/03/economist-explains-why-south-africa-BRICs.

The Economist (2013b) "Emerging economies: When giants slow down," The Economist, July 27. Available at: http://www.economist.com/news/briefing/2158 2257-most-dramatic-and-disruptive-period-emerging-market-growth-world-hasever-seen.

Tostevin, M. (2010) "Should South Africa be a BRIC?," Reuters, November 17. Available at: http://blogs.reuters.com/africanews/2010/11/17/should-southafrica-be-a-bric/.

Wan, W. P. (2005) "Country resource environments, firm capabilities, and corporate diversification strategies," Journal of Management Studies 42 (1), 161-182.

Wan, W. P. and R. E. Hoskisson (2003) "Home country environments, corporate 
diversification strategies, and firm performance," Academy of Management Journal 46 (1), 27-45.

Wilson, D. and R. Purushothaman (2003) "Dreaming with BRICs: The path to 2050," Goldman Sachs Global Economics Paper, No. 99, New York.

Yardley, J. (2012) "For group of five nations, acronym is easy, but common ground is hard," The New York Times, March 29. Available at: http://www. nytimes.com/2012/03/29/world/asia/plan-of-action-proves-elusive-for-emergingeconomies-in-BRICs.html?_r $=0$. 